\title{
New Paradigm in Natural Resources Management: Securing Indigenous Peoples Rights
}

\author{
Farida Patittingi \\ Faculty of Law, Hasanuddin University, Indonesia. E-mail:farida.pada@unhas.ac.id
}

\begin{tabular}{l} 
ARTICLE INFO \\
\hline Keywords: \\
Customary Law; Forest; \\
Indigenous Peoples; Land; \\
Natural Resources \\
How to cite: \\
Patittingi, F. (2020). New \\
Paradigm in Natural \\
Resources Management: \\
Securing Indigenous Peoples \\
Rights. Hasanuddin Law \\
Review, 6 (1): 56-65 \\
DOI: \\
10.20956/halrev.v6i1.2267 \\
\hline
\end{tabular}

\begin{abstract}
The multi-decade struggle of indigenous communities in Indonesia to gain recognition of their collective rights and the reluctance of the state to act on their demands, now has come to a bright spot. The rights of indigenous peoples in natural resources management -in land and forests-get more recognition as well as protection since the Constitutional Court's decision on forest law. The recognition of indigenous peoples and their traditional rights must be followed by exclusive rights to control and managing resources in their environment, such as land or forests, as the main source of livelihood for indigenous peoples (lebensraum). Hence, a legal policy is needed from the government that regulates and provides strict and clear recognition criteria for its existence and their rights to natural resources.
\end{abstract}

Copyright $@ 2020$ HALREV. All rights reserved.

\section{Introduction}

Indonesia, as many developing countries, the government is struggling to improve the management of their dwindling forest resources. ${ }^{1}$ Despite government efforts, Indonesia still has large tracts of primary and secondary forest ecosystems that are under intense threat from both industry and local people. However, as it turns out into practice, indigenous peoples with all their traditional rights to natural resources have gained recognition both nationally and internationally. ${ }^{2}$ In international level, various

1 Fay, Chip, Ho-Ming So Denduangrudee, J. F. McCarthy, and K. Robinson. "Emerging options for the recognition and protection of indigenous community rights in Indonesia." Land and Development in Indonesia: Searching for the people's sovereignty (2016): 91-112.

2 Among others, ILO's Convention No. 169 concerning Indigenous Peoples and Tribunal People in Independent State, stipulates that governments must respect the culture and spiritual values of indigenous peoples who are held in high esteem in their relations to the land they occupy or use. Yupsanis, A. (2010). ILO Convention No. 169 Concerning Indigenous and Tribal Peoples in Independent Countries 1989-2009: An Overview. Nordic Journal of International Law, 79(3), 433-456. 
conventions have confirmed this subject. In national context, this recognition is expressly stated in the constitution as affirmed in the 1945 Constitution, Article 18B para. (2), where State recognizes and respects the customary law community units with their traditional rights as long as they are still alive and in accordance with the development of community and the principles of the State.

However, the recognition of indigenous peoples position and their traditional rights by the State is still in the juridical-normative level which seems difficult to be realized because as the following requirements: (a) they are still alive; (b) in accordance with the development of society; (c) the principle of the Unitary State of the Republic of Indonesia; and (d) as regulated in the law. These requirements still require further elaboration and confirmation in order to obtain legal certainty and protection for the existence of the customary law community.

Certainly, the recognition of indigenous peoples and their traditional rights must be followed by exclusive rights to communities to control and manage the resources in their environment i.e land or forests, which are the main source of livelihood for indigenous peoples (lebensraum). One of the areas which are an inseparable part of the customary community is the forest, because it is one of the wealth of the indigenous peoples besides the land as the place where the forest grows. According to them, the relationship of the human and its surrounding nature is a religius-magical relationship that cannot be separated each another.

In general, indigenous peoples consider that humans are part of nature that must maintain and balance each other and create harmony between them. To maintain harmonious between people and their land and forests, in general they develop the concept of possession (property rights) communally and exclusively for customary forest area. ${ }^{3}$ Hence, in order to support the management of customary forests as common rights, the customary communities have a system of governance in forest management, customary law and customary institutional structure (governance) that provide the ability to solve the problems they face. Customary law is the most important social institution for the community to secure resources within the customary forest area from excessive utilization, both by the community and outside parties.

\section{Indigenous Peoples in Legal Perspectives}

As the topic given using the term indigenous peoples, it is necessary to first describe the use of the term indigenous peoples that often equated with the term customary law communities. Academic studies by several experts have provided a theoretical basis from the background of using these two terms. The term masyarakat adat is taken from the translation of the word "indigenous peoples", while the term masyarakat hukum adat is a translation of the Dutch's term "rechtsgemenschap". The term "rechtsgemenschap" is a term associated with the term "adatrecht" which was popularized by Cornellis Van Vollenhoven in his book Het Adatrecht van Netherland Indie. 4 They give a broader meaning to the term indigenous peoples when compared with the term customary law communities.

3 In this case, an example is the development of a system of possession of land and forests that exist in the territory of the customary law community "Ammatowa" in Bulukumba district, where the control, management and utilization of land and forests are regulated and led by Ammatowa.

4 Alting, H. (2010). Dinamika Hukum Dalam Pengakuan dan Perlindungan Hak MAsyarakat Hukum Adat atas Tanah (Masa Lalu, Masa Kini dan Masa Mendatang), LaksBang PRESSindo, Yogyakarta, p. 80 
The term indigenous people are believed to have a broad dimension of meaning than just a legal aspect, because in indigenous peoples it is very closely related to the cultural, religious, and so on. At the Congress "Masyarakat Adat Nusantara I" was held in March 1999, it was agreed that "indigenous peoples are a group of people who have ancestral origins (hereditary) in certain geographical areas and have a system of values, ideology, economics, politics, culture, social and territory." While, in ILOs Convention No. 169 of 1999 concerning Indigenous and Tribunal People in Independent State defines "indigenous peoples" as tribes who reside in an independent State in which social, cultural and economic conditions differ from other community groups or tribes who resides a country since the colonial period and has economic, cultural and political institutions.

F.D. Hollemann in his book "De Commune Treck in het Indonesische Rechtsleven"5 constructs 4 (four) common traits of indigenous peoples i.e religious-magical, communal, concrete and cash. These characteristics can be described as follows: the first, religious-magical, it is interpreted as a mindset based on people' beliefs about the existence of something that is sacred. Before the community came into contact with the religious legal system, religiosity was manifested in pre-logical mindset, animism and supernatural belief. The community must maintain harmony between the real and inner world (supernatural). After the community knows the religious legal system, religiosity is manifested in the form of belief in God. They believe that any act of any kind will always be rewarded and punished by God according to their mistakes (action).

The second is communal. The community has the assumption that every individual is an integral (inseparable) part of society as a whole. It is believed that individual interests should be appropriately adjusted to the interests of the community because no individual is independent of the community. The third is concrete. It is interpreted as a pattern that is completely clear or real shows that every legal relationship that occurs in the communities is not done secretly or vaguely. The fourth is cash (kontante bandeling). It is interpreted as participation especially in the fulfillment of achievement. It means that every fulfillment of achievement is always counter-achievement given instantaneously.

Meanwhile, some experts consider the term customary law communities is only narrow indigenous peoples entities to the extent of legal entities, but in terms of juridicalnormative, the term of customary law communities are more appropriate when related to the existence of indigenous peoples and their rights, because the existence and rights are actually in the customary law community which is governed by the customary law itself. Likewise, if we tracking a variety of laws and regulations include the 1945 Constitution, it is precisely the term "customary law community" is used. Kusumadi Pujosewojo $^{6}$ gave the understanding of the customary law community that the customary law community is a community that arose spontaneously in certain areas, its establishment was not ordered by a higher authority or other, with a very great sense of solidarity among members, view non-community members as outsiders and use their territory as a source of wealth that can only be fully utilized by their members. He distinguishes the customary law community from the law community

\footnotetext{
Salman, O. (2002). Rekonstruksi Hukum Adat Kontemporer, PT. Alumni, Bandung, p. 29-30

Sumardjono, M.S.W. (2001). Kebijakan Pertanahan, Antara Regulasi dan Implementasi, Kompas, Jakarta, p. 56
} 
which is defined as a society that establishes, bound and subject to its own legal system.

Ter Haar ${ }^{7}$ provides an understanding of the customary law community as an organized, permanent group of people having their own power and wealth, both material and immaterial, where each group experience life in society as a usual thing according to the nature and none of the members has the mind to dissolve it, or break away from that bond forever. The customary law as a precipitate of social wealth that is supported and maintained by the decision of the holder of power or head of the people and meeting imposed on a legal action or a dispute (beslissingen).

Meanwhile, according to Wignjodipuro in Farida Patittingi, 8 the customary law community (the association of customary law) is a unit that has an orderly and eternal arrangement and has its own management and wealth, both material and immaterial wealth. In Indonesia, the customary law communities can be established by heredity (genealogical), the similarity of territorial, and both (genealogical-territorial). As the expert's opinion, it can be concluded that the characteristics of customary law community (adatrechtsgemenschap), includes: (1) an organized human unity; (2) reside in a certain area; (3) presence of rulers; (4) wealth, both material and immaterial wealth; (5) has a system of values and beliefs; and (6) has its own legal structure.

\section{Rights of Indigenous Peoples in Natural Resource Management}

In concept, as explained earlier, a community can be categorized as a customary law community, if it still has the characteristics as stated by the customary law experts above. However, in the context of legal policy, all of these characteristics must be confirmed in a legal regulation, so that they can become a general reference to determine the existence of a customary law community and their traditional rights. Recognition of the existence of these customary law communities has consequences for their rights to natural resources in their territory as well as statements of the authority of customary law communities to regulate and manage the resources in these areas.

The rights of the customary law community are formulated as communalistic religious communal rights. This communalistic refers to the common rights of customary law community over a resource (such as the land and plants on it, in this case including forests). It is a common right of customary law community who are believed to be gifts of supernatural powers or ancestors inheritance to groups which are customary law communities, as the main supporting elements for the life and livelihood of these groups of all time.

These common resources are not only for the fulfillment of the needs of a generation but are intended as the main supporting element in the lives and livelihoods of past, present and future generations. In the context of this interest, the customary law community is burdened with the obligation to manage it well and be used to meet common needs. The designation, control, utilization and maintenance needs to be regulated by the group, so that in addition to being carried out in an orderly to avoid disputes, there will also be a preservation of its ability as a future generation. This is the concept of sustainable resource management from the customary law communities.

\footnotetext{
7 Haar, T. (2001). Asas-Asas dan Susunan Hukum Adat (Translated by K.Ng.Soebakti Poespono). Pradnya Paramita, Jakarta, p. 28

8 Patittingi, F. (2013). Dimensi Hukum Pulau-Pulau Kecil di Indonesia, Rangkang Education, Yogyakarta, pp. 103-104
} 
Maintaining the natural environment is keeping life itself, on the contrary destroying the natural environment means destroying the life itself. Therefore, in the concept of customary rights there are 2 (two) legal concepts, i.e the common rights for land along with existing plants on it which are included in the field of civil law, as well as containing the duties of managing, regulating and leading the mastery, maintenance, designation and utilization are included in the field of public law.

In the concept of customary law, the delegation of duties of authority which includes the field of public law does not cover or affect the legal relationship with shared land which has a civil law perspective. The right of ownership to the shared land still rests with the customary law community, which means it remains with the peoples and does not transfer to the custom head. The common rights are not property rights in the juridical sense but rather the common property rights of all communities.

According to Boedi Harsono, ${ }^{9}$ customary rights are the rights of a customary law community over the territorial, which gives certain authority to the customary authorities to regulate and lead the utilization of the territory of the customary law community. Meanwhile, Maria S.W. Sumardjono stated that customary right is a technical term that shows the inherent rights as a specific competence in the customary law community, in the form of authority to manage and regulate land. According to Maria S.W.Sumardjono, the customary rights are not only the land with all the plants or animals on it, but also to the water and the resources contained therein.

Conceptually, as described above the rights of customary law communities to natural resources (ie land and forests) not only contain elements of possession but also to manage. Therefore, in the present context, it is necessary to support legal policy from the government so that the legal protection of the existence of customary law communities along with their traditional rights obtains legal certainty.

It is important, as analysis of experts and the public at large see that the recognition given by the State to the existence of customary law community at the level of laws and regulations is still considered limited to juridical-normative recognition, which is difficult to fulfill by the customary law community itself or related parties. Such an assumption is due to the existence of some stringent requirements that accompany the acknowledgment. Such as the recognition of indigenous peoples and their traditional rights in the 1945 Constitution or the recognition of customary law community rights in the Basic Agrarian Law still requires clarity on the requirements that follow.

For example, Article 3 of the Basic Agrarian Laws stipulates that "Considering in mind the provisions in Articles 1 and 2, the implementation of customary rights and similar rights of indigenous peoples as long as in fact they still exist, must be such that they are in accordance with the interests national and state based on national unity and may not conflict with other higher laws and regulations." There are 2 (two) requirements that follow: (a) existence, that as long as in fact it still exists; and (b) implementation, in accordance with national and State interests and does not conflict with other higher laws and regulations.

All of these requirements still require clarity and legal agreement in order to become a shared guideline between the government representing the interests of the State and customary law community who need protection in the enforcement of their rights. In addition to the rights of customary law community to the land resources that constitute their lebensraum, forests are also an entity that gives an important position to the

$9 \quad$ Ibid, p. 122 
customary law community, because in that forest they can also obtain livelihoods. By the importance of forests for them, so that one of the exclusive rights granted to customary law communities over forests is the right to collect forest products.

In the context of forest tenure and management based on the Law No. 41 of 1999 concerning Forestry (Forestry Laws), customary law community still receive recognition and respect, but again with the fulfillment of several requirements. For example, in Article 4 paragraph (2) of the Forestry Laws emphasizes that "forest tenure by the State continues to pay attention to the rights of customary law community, as long as in reality it still exists and it is recognized, and it does not conflict with national interests."

The form and substance of the recognition of the forestry laws on the rights of customary law community to forests seems to continue the concept of the recognition of customary rights by Agrarian Law that is "as long as in reality it still exists, it is recognized and it does not conflict with national interests." The conditional recognition is also still framed by the concept of State control over forests as affirmed in Article 4 paragraph (1) of the Forestry Laws, that "all forests within the territory of the Republic of Indonesia including natural resources contained therein are controlled by the State for the greatest prosperity of the people". In implementing the right of State to control over forests, the Forestry Law was instructed to continue to pay attention to the rights of customary law community.

\section{New Paradigm in Law: The Rights of Customary Law Community as Constitutional Rights}

The development of the rights of customary law community to natural resources especially land and forests experiences significant changes after the Constitutional Court Decree No. 35/PUU-X/2012. In earlier, the concept of the Basic Agrarian Law was different from the Forestry Law. Agrarian Law distinguishes land in three categories, i.e State land, right land and customary land, while the Forestry Law only divides forests in two categories, State forest and private forest. In State forest the customary forest is included, so that legally the existence of the customary forest must be in the frame of the State forest, as specified in Article 5 paragraph (1) and (2). Article 5 paragraph (1) of the Forestry Law stipulates that "forests based on their status consist of: a. State forest and b. right forest. Then, in Article 5 paragraph (2) determines that "State forest as referred to in paragraph (1) letter $a$, can be in the form of customary forest." The determination of customary forest is done by the government on the condition, "as long as in reality accordance with the customary law community and it is recognized". 10

An important point in the Constitutional Court decree is to give a strong status to the customary law community for the management of forest resources, because the decree provides recognition of customary forests that are no longer included as part of the State forest. Therefore, the existence of customary forests that can be exclusively managed by customary law communities is very much determined by recognition from the government. Thus, in order to avoid arbitrariness in determining the status of forests by the government, it is necessary to formulate a legal policy regarding these

10 The Constitutional Court Decision Number 35/PUU-X/2012 regarding the judicial review of the Law No. 41 of 1999 concerning Forestry. 
criteria in the form of strict legislation so that they can become a common reference in determining the status of the forest. ${ }^{11}$

All winged legal policy weakens the position of the customary law community to resources management (forest), so that it requires systematic and continuous advocacy from all elements of the community to formulate a legal policy that provides legal certainty and protection. In the Forestry Law, the procedure for implementing the rights of customary law community (which in reality still exists and recognizes its existence) is related to the forest as stipulated in Article 67 paragraph (1), namely:

a. To collect forest products to meet the daily needs of the indigenous peoples concerned;

b. To conduct forest management activities based on existing customary law and not in conflict with the law; and

c. Empowerment in order to improve their welfare

The elucidation of Article 67 paragraph (1) determines that the existence of customary law communities is recognized if in reality it meets elements including: (a) the community is still in the form of an association (rechtsgemenschap); (b) an institution in the form of customary authorities; (c) a clear customary law area; (d) institutions and legal instruments especially traditional hearing are still adhered to; and (e) still collect forest products in the surrounding forest area to fulfill daily needs.

The recognition of existence and elimination of the customary law community as referred to in paragraph (1) shall be stipulated by a regional regulation. Further, paragraph (3) stipulates that further provisions regarding the determination of the existence of customary law community and their rights relating to forests are regulated by government regulation.

In the elucidation of paragraph (1) is determined that the regional regulation is prepared by considering the results of research by customary law experts, the aspirations of local communities and traditional community leaders in the area concerned and other relevant institutions or parties. Elucidation of paragraph (3) that the government regulation contains rules including: (a) procedures for evaluation; (b) involved parties; (c) research material; (d) criteria for evaluating the existence of customary law community.

Hence, the form of recognition for the existence and elimination of customary law community in the forestry law must be determined by a regional regulation which had to be regulated in the government regulation. However, until now, the government regulation referred to has not yet been issued. The legal vacuum was then anticipated by the Minister of Forestry by making Circular No.75/Menhut-II/ 2004 concerning Customary Law and Compensation Claims by the Customary Law Community. Circular addressed to Governors and Regents/Mayors throughout Indonesia contains provisions as further elaboration.

11 Nur, J., Patittingi, F., Salle, A., and Saad, S. (2019). Environmental rights of the indigenous peoples of Moronene Hukaea Laea in the national park conservation area, IOP Conference Series: Earth and Environmental Science, Vol. 343: 1-5. 
In order to accommodate the demands of the customary law community, the Governors and Regents/Mayors throughout Indonesia are requested to take the following steps:

a. If in the territory there is a claim by the customary law community in the forest area that has been encumbered with Forest Concession Rights/Business Permit for Timber Forest Product Utilization (IUPHHK - Hak Pengusahaan Hutan/Izin Usaha Pemanfaatan Hasil Hutan Kayu), then the request or demand needs to be previously carried out research by customary law experts, community leaders existing in the area concerned, agencies or other parties concerned and pay attention to the aspirations of the local community to determine whether the request in question is still a customary law community or not. It must refer to the criteria of the existence of customary law community as specified in the Elucidation of Article 67 paragraph (1) of the Forestry Law.

b. To set a State forest as a customary forest whose management is handed over to the local customary law community (rechtsgemenschap), the Regent/Mayor proposes the State forest to be designated as a customary forest by containing the location, area and map of the customary forest proposed to the Minister of Forestry with the recommendation of the Governor with provisions as long as according to the fact the customary law community concerned are still in existence (de facto) and their existence is recognized (de jure).

c. If based on the research results the request meets the requirements, so that the customary law community can be stipulated by a Provincial Regional Regulation.

d. Then, the Regional Regulations on the existence of customary law community are submitted to the Minister of Forestry to submit a request for the determination as customary forests. Upon the request, the Minister of Forestry can accept or reject the determination of customary forests.

e. If based on the request the Minister of Forestry can accept, then a customary forest will be established for the community concerned. Based on the provisions of the Minister of Forestry regarding the determination of the customary forest to be sent to you, we ask that you help to be able to facilitate a meeting between the customary law communities (which have been established) and HPH/IUPHHK holders.

f. As with compensation claims by customary law community to HPH/IUPHHK holder that conduct activities or operations in the area of customary law community, compensation does not have to be in the form of money, but can be in the form of new livelihoods or involvement in business the use of the surrounding forest or the construction of public or social facilities that are beneficial to local customary law communities and within reasonable limits or not excessive, and do not have extortion tendencies and in order to improve the welfare of customary law communities.

g. The claim of compensation by the customary law community against $\mathrm{HPH} / \mathrm{IUPHHK}$ holders, the Governor/Regent/Mayor can facilitate a meeting between the parties concerned for solution through deliberation and consensus. However, if there is no meeting point, then the solution is suggested to be done through a court process by filing a civil suit through the general court.

In addition, customary law community also has the opportunity to manage forests with special objectives as determined in Article 8 of Forestry Law. The designation of forest areas with special objectives is needed for public purposes, such as (a) research and development; (b) education and training; and (c) religious and cultural. 
All forms of juridical-normative recognition to the existence of customary law community and their traditional rights, particularly their rights related to forest management, at the implementation level still have various obstacles, includes: the first, conditional recognition which still requires firmness. In the aspect of legal instruments has recognized the existence of customary law community, but it is trouble at the level of implementing regulations which will assert various conditions for recognition. Even though the condition "as long in reality still exists" has been given the criteria in the Elucidation of Article 67 paragraph (1), but how to measure the condition "it is not conflict with national interests and higher legislation"? This still requires a long discussion to get agreement between the customary law community and related parties, especially the government.

The second, the recognition of the existence of customary law community and their rights is delegated to the regional government in written in the form of a regional regulation. Also, this requires research and commitment from the regional government to provide recognition. The third, the recognition of customary law community rights to forests also requires quite lengthy and tortuous procedures that must be based on government regulations, while the government regulations have not yet been issued.

The fourth, because the government regulation has not yet been issued, for the temporary, the basic procedure for the recognition of customary law community and their rights and the determination of a State forest to be customary forest is only based on Circular, while the Circular is not a binding legal regulation, so it can be ignored by the regional government (province and regency/city) without any sanctions for the regional government. Last but not least, the problematic of the management are of customary law community over forest resources at the level of legal policy still need clarity in order to provide legal certainty, and the commitment of government to implement the legal policy is needed in order to provide legal protection to customary law community.

\section{Conclusion}

The implementation of the rights of customary law community over natural resources (i.e land and forests) will be highly determined by the existence of legal policy from the government which regulates and provides strict and clear recognition criteria for their existence along with their rights over certain resources, by regulating the designation, control, utilization and maintenance of resources. Recognition of customary law communities and their rights in various laws and regulations is still difficult to fulfilled by the customary law communities because it still require strict requirements and tend to weaken the position of the customary law community itself.

In the future, it is hoped the State can consistently give recognition to the existence of customary law community and their rights by providing clarity on all these strict requirements so that the mandate of constitutional to provide welfare and protection to all Indonesian people can be realized immediately. 


\section{References}

Alting, H. (2010). Dinamika Hukum Dalam Pengakuan dan Perlindungan Hak MAsyarakat Hukum Adat atas Tanah (Masa Lalu, Masa Kini dan Masa Mendatang), LaksBang PRESSindo, Yogyakarta.

Fay, Chip, Ho-Ming So Denduangrudee, J. F. McCarthy, and K. Robinson. "Emerging options for the recognition and protection of indigenous community rights in Indonesia." Land and Development in Indonesia: Searching for the people's sovereignty (2016): 91-112.

Haar, T. (2001). Asas-Asas dan Susunan Hukum Adat (Translated by K.Ng.Soebakti Poespono). Pradnya Paramita, Jakarta.

Nur, J., Patittingi, F., Salle, A., and Saad, S. (2019). Environmental rights of the indigenous peoples of Moronene Hukaea Laea in the national park conservation area, IOP Conference Series: Earth and Environmental Science, Vol. 343: 1-5.

Patittingi, F. (2013). Dimensi Hukum Pulau-pulau Kecil di Indonesia, Rangkang Education, Yogyakarta.

Salman, O. (2002). Rekonstruksi Hukum Adat Kontemporer, PT. Alumni, Bandung.

Sumardjono, M.S.W. (2001). Kebijakan Pertanahan, Antara Regulasi dan Implementasi, Kompas, Jakarta.

The Constitutional Court Decision Number 35/PUU-X/2012 regarding the judicial review of the Law No. 41 of 1999 concerning Forestry.

Yupsanis, A. (2010). ILO Convention No. 169 Concerning Indigenous and Tribal Peoples in Independent Countries 1989-2009: An Overview. Nordic Journal of International Law, 79(3), 433-456.

\section{Conflict of Interest Statement:}

The author(s) declares that the research was conducted in the absence of any commercial or financial relationships that could be construed as a potential conflict of interest.

Copyright (C) 2020 HALREV. All rights reserved. 